\title{
Maiêutica socrática e comunicação digital: paixão e persuasão em tempos de pandemia
}

\author{
Aidil Soares Navarro \\ Claudia Rodrigues da Silva Nascimento
}

De modo análogo, é preciso que ele compreenda a natureza da alma, descubra a classe de discurso que se ajusta a cada natureza, organize e ordene seu discurso em consonância com isso, proporcionando discursos elaborados e harmoniosos às almas complexas, e simples conversações às almas simples. Enquanto não executar isso, não se capacitará a empregar o discurso com arte, na medida em que se possa controlar metodicamente um discurso, quer com propósitos de ensino, quer com propósitos de persuasão. ${ }^{1}$

o fechamento da segunda década do século XXI, mais uma vez tivemos a
confirmação de uma máxima: o tempo passa linearmente, mas os cenários e
as situações estão e sempre estarão em constante mutação. Por isso, eles sempre
requererão adaptações às novas demandas e novas formas de interação. Junto
com eles estabelecem-se constantes reestruturações em todos os segmentos
da sociedade. No caso do universo do ensino, elas chegam acompanhadas de
inquietações, de desconforto não só aos educadores, mas também ao alunado.
Essa foi a situação vivida no início do ano letivo de 2020 em decorrência da ins-
talação da pandemia do Covid-19, e que serviu como um mecanismo de disparo
para a efetivação da tecnologia como recurso pedagógico para o ensino remoto.
A mudança no cenário educativo estava posta tendo em vista os recursos
tecnológicos como ferramenta pedagógica, contudo, em decorrência do isola-
mento social, o professorado foi compelido a criar métodos de ensino remoto e

$1 \quad$ Aristóteles, 2013, p. 109 
a harmonizar o uso das tecnologias com a arte do bem falar. Esta última é uma estratégia já usada pelo filósofo Sócrates a fim de levar seu auditório para uma reflexão filosófica por meio de questionamentos, que o induziam a raciocinar sobre a subjetividade de um problema.

O presente trabalho tem como objetivo verificar a contribuição da maiêutica socrática e entender a importância da construção de argumentos na comunicação digital, em especial em tempos de pandemia. Nesse sentido, a retomada do princípio da maiêutica solidifica-se em questões que induzem ao raciocínio, ação que consideramos essencial para desenvolver um trabalho pedagógico significativo, ainda mais no contexto de ensino remoto justificado pelo isolamento social.

Assim, este estudo norteou-se pela seguinte pergunta de pesquisa: como os professores movidos pelas paixões (temor e confiança) aplicaram a maiêutica socrática em tempos de pandemia durante o ensino remoto? O corpus para análise foi composto por depoimentos de professores de uma escola municipal de Santo André, no ABC Paulista, no Estado de São Paulo, nos quais destacamos os desafios com que se depararam os professores nessa modalidade de ensino remoto e as paixões envolvidas para enfrentar os obstáculos e, simultaneamente, vislumbrar uma solução.

Em virtude da repentina mudança advinda da implantação do ensino remoto, os professores precisaram se adequar aos recursos tecnológicos e às novas formas de comunicação, o que exigiu esforço para desenvolverem um trabalho de qualidade no meio digital. Com relação ao referencial teórico, apoiamo-nos em Platão (2004), Aristóteles (2000), Ferreira (2010), Meyer (2007), Perelman e Olbrechts-Tyteca (1996).

\section{O Método Socrático}

Sócrates, um nato orador, ganhou fama de "pai da filosofia" devido às suas características, incomuns para a época. Ao contrário de seus contemporâneos, ele não visava à definição de conceitos; em vez disso, "dialogava e forçava o interlocutor a expor suas opiniões, com habilidade, emaranhá-lo na teia obscura de suas próprias afirmativas, acabando por reconhecer sua ignorância a respeito do que antes julgava ter certeza".

A afirmação "forçava" diverge do conceito da persuasão, assim concordamos que são práticas distintas. De acordo com Rodrigues, "o Método Socrático manifesta a oposição de Sócrates à retórica como uma forma de arte que visa agradar aos ouvintes e também à oratória, que convence por vias emocionais". ${ }^{3}$ 
Maiêutica socrática e comunicação digital:

paixão e persuasão em tempos de pandemia

Por meio da "injunção délfica" - "Conhece-te a ti mesmo" -, o filósofo destacava a importância de reconhecer a si mesmo, uma possível indicação de caminho, que conduzia às boas práticas morais, por fazer seu interlocutor desenvolver uma linha lógica, ou seja, um fio condutor que despertava o conhecimento existente no interior do indivíduo. Ele abdicou de uma vida social de luxo para dedicar-se aos interesses dos atenienses e seu prazer resumia-se à discussão em lugares públicos, que nem sempre era bem vista. Devido a sua simplicidade como filósofo ambulante, foi hostilizado e maltratado inúmeras vezes.

Sócrates não deixou textos escritos. Foi retratado nas obras de Xenofonte, seu contemporâneo no exército ateniense, de Platão, seu discípulo, bem como de Aristófanes, e também de Aristóteles, que não chegou a conhecer Sócrates pessoalmente, porque nasceu cerca de quinze anos após a morte dele. ${ }^{4}$

Mesmo sem deixar textos escritos, destacou-se como incansável procurador do conhecimento. Foi o idealizador da maiêutica e da prática dialogal, o que lhe garantiu inimigos ao longo da vida, por fazer uso da ironia com seus interlocutores. ${ }^{5}$ Apesar de não ser um sofista, desenvolveu a arte de ensinar e foi considerado um retor.

O método socrático maiêutico dividia-se em duas vertentes, a ironia e a maiêutica, Antiseri e Reale esclarecem:

A ironia é a característica peculiar da dialética socrática, não apenas do ponto de vista formal, mas também do ponto de vista substancial. Em geral, ironia significa "simulação". Em nosso caso específico, indica o jogo brincalhão, múltiplo e variado das ficções e dos estratagemas realizados por Sócrates para levar o interlocutor a dar conta de si mesmo.

Nota-se que, às vezes em suas simulações irônicas, Sócrates fingia até mesmo acolher como próprios os métodos do interlocutor, especialmente quando este era homem de cultura, particularmente um filósofo, e brincava de engrandecê-lo até o limite da caricatura, para derrubá-los com a mesma lógica que lhes era própria e amarrá-lo na contradição. ${ }^{6}$

A ironia socrática relaciona-se ao ato de perguntar: "assume a posição de questionador: age interrogando aqueles que dizem possuir algum saber, fingindo

4 Carrasco, 2013, p. 11

Carrasco, 2013

Antiseri e Reale, 2003, p.101 
ter a intenção de aprender algumas coisas com eles". 7 Além disso, a respeito da expressão "ironia socrática”, destacamos outra particularidade:

(...) sempre entre aspas, como sinônimo do termo grego eironeía não só por ser a forma consagrada de referência a essa singular atitude ou maneira de argumentar de Sócrates, mas também para deixar claro, no uso das aspas, o quanto nos distanciamos criticamente desse uso por parte de Vlastos ${ }^{8}$ e de comentadores não muito atentos - devido às suas teses e posições exegéticas quanto aos diálogos - à radical diferença de significado e de pertinência que enxergamos e valorizamos entre a dita "ironia" moderna e a antiga eironeía. ${ }^{9}$

A segunda vertente é a maiêutica, esta faz referência ao trabalho de parto. Por ser filho de mãe parteira, Sócrates associou o ofício materno à possibilidade de "auxiliar" as pessoas a darem à luz ideias. Nesse sentido, acreditava que uma pergunta feita corretamente induziria a pessoa ao raciocínio e à elucidação de ideias complexas sobre determinada temática.

Nesse sentido, a capacidade de se moldar e se adaptar a cada circunstância está atrelada à maiêutica. Por meio do diálogo, do debate e de perguntas bem elaboradas, induz à reflexão como rumo a um "conhecimento que traz em si, os altos valores da existência humana". ${ }^{10}$

O discurso socrático se manifesta por meio de instrumentos dialógicos e por discussões, nas quais os argumentos podem provocar as mais diversas paixões no auditório. Assim como na maiêutica socrática, o professor de hoje, ao trabalhar com o ensino remoto, precisa se aproximar do alunado e propor atividades com questões que o induza a fazer reflexões, buscar adequações tanto na intervenção quanto nos recursos tecnológicos.

\section{As paixões}

De acordo com o dicionário Caldas Aulete (2008), a paixão é uma emoção ou sentimento muito forte (amor, ódio, desejo etc.) capaz de alterar o comportamento, o raciocínio, a lucidez. Já para Aristóteles, as paixões são “todos aqueles sentimentos que, causando mudança nas pessoas, fazem variar seus

\footnotetext{
Afonso, 2016, p. 80

Gregory Vlastos foi um estudioso da filosofia antiga e autor de vários trabalhos sobre Platão e Sócrates.

Campos, 2016, p. 21

10 Maia, 2008, p. 48
} 
Maiêutica socrática e comunicação digital:

paixão e persuasão em tempos de pandemia

julgamentos, e são seguidos de tristeza e prazer, como a cólera, a piedade, o temor, a confiança e todas as outras paixões análogas". ${ }^{11}$

Portanto, por meio das paixões, é possível persuadir pela disposição dos ouvintes, quando eles são levados a sentir emoção por meio do discurso, pois os juízos que emitem variam conforme sentem tristeza ou alegria, amor ou ódio. ${ }^{12}$ No livro I da Retórica, Aristóteles textualiza:

persuade-se pelo caráter quando o discurso é proferido de tal maneira que deixa a impressão de o orador ser digno de fé. Pois acreditamos mais e bem mais depressa em pessoas honestas, em todas as coisas em geral, mas sobretudo nas de que não há conhecimento exato e que deixam margem para dúvida. É, porém, necessário que esta confiança seja resultado do discurso e não de uma opinião prévia sobre o caráter do orador; pois não se deve considerar sem importância para a persuasão a probidade do que fala, como aliás alguns autores desta arte propõem, mas quase se poderia dizer que o caráter é o principal meio de persuasão. ${ }^{13}$

Desse modo, as paixões se relacionam "às soluções opostas, aos conflitos, à diferença entre os homens" 14 e movem as pessoas a terem a atitude, a transformá-la, conforme afirma Meyer:

as paixões refletem, no fundo, as representações que fazemos dos outros (...) as paixões constituem um teclado no que o bom orador toca para convencer. Um crime horrível deve suscitar indignação, ao passo que um delito menor, absolutamente perdoável, deve ser julgado com compaixão. Para despertar tais sentimentos, é preciso conhecer os que existem antes de tudo no instigador do auditório. Há aí uma verdadeira dialética passional, que se enreda sempre em retórica com um ajuste das diferenças, das contestações, o que deve chegar para que haja persuasão, a uma identidade, o ideal político de toda relação com outrem. ${ }^{15}$

\footnotetext{
11 Aristóteles, 2000, p. 5

12 Id., 1998

13 Id., 2013, p. 63

14 Meyer, 2000, p. XXXV

15 Ibid., p. XLI
} 
Em suma, é possível afirmar que "a paixão como resposta problematológica adquire uma positividade (...) que nos interpela, voz do outro e da resposta que ela solicita, concomitantemente problema e solução". ${ }^{16}$ Nesse sentido, Meyer ainda afirma

a paixão é o discurso do eu que se reflete em relações irrefletidas. Compreende-se que ela participe da consciência e do inconsciente, da ação e do pensamento, do sentimento e também da razão, de uma outra visão da razão. Talvez a consciência se prenda ao pathos, ao passional, porque ela não é apenas essa reflexividade da certeza apodítica; é também a temporalidade de nossos sentimentos, os quais verdadeiramente, poderiam arremessar-nos para além da separação da consciência e do inconsciente, para o domínio mais próximo de sua origem. ${ }^{17}$

\section{O temor e a confiança}

O vocábulo temor, conforme o dicionário Michaelis (2015), deriva do latim timor, e refere-se ao ato ou efeito de temer; uma sensação de ameaça; susto. Um sentimento de profundo respeito ou de reverência. Alguém ou algo que provoca medo. Pode estar associado a receio, susto, medo, pavor, terror. O Minidicionário da Língua Portuguesa apresenta o significado de "sensação de instabilidade, de ameaça ou de dúvida". ${ }^{18}$

Assim, o temor se manifesta em situações variadas e pode se relacionar a coisas, a pessoas, bem como a injustiça, a morte, a incerteza. Conforme Aristóteles, "o temor é uma espécie de pena ou de perturbação, causada pela representação de um mal futuro e suscetível de nos perder ou de nos fazer sentir pena.. ${ }^{19}$ Em síntese,

é terrível tudo o que sobrevém ou pode sobrevir a nossos semelhantes, suscetível de provocar a compaixão. Eis o que, mais ou menos, de importante se pode dizer sobre o que é capaz de provocar o temor e sobre o que de fato tememos. ${ }^{20}$ 
Maiêutica socrática e comunicação digital:

Em tempos de pandemia, o temor motivou cada professor a "conhecer a si mesmo" e o fez inovar em suas habilidades e competências para dar continuidade ao seu trabalho. Consequentemente, o docente passou a substituir o temor pela esperança e pela confiança, ação descrita por Aristóteles como necessária para "que haja alguma esperança de salvação pela qual valha a pena lutar". ${ }^{21}$

Quanto à confiança, o dicionário Larousse Cultural (1999) informa que confiar se origina do latim confidere, que significa ter confiança ou fé. Confiança significa esperança firme em alguém, em alguma coisa. É um sentimento de segurança quanto à probidade da conduta de determinada pessoa. No minidicionário Aurélio século XXI escolar, essa paixão é referida como "segurança íntima de procedimento, crédito, fé. Boa fama." 22

De acordo com Aristóteles, "a confiança é o contrário do temor e o que inspira confiança é o contrário do que provoca temor" ${ }^{23}$ Além disso, o filósofo grego enumera o que nos torna sensíveis ao temor: (1) quando pensamos ter sido bem-sucedidos em muitas coisas; (2) quando vemos que nossos semelhantes não experimentam nenhum temor; (3) quando julgamos ter as vantagens que asseguram a superioridade e inspiram temor aos outros; (4) quando nunca prejudicamos a ninguém ou se lesamos só poucas pessoas das quais nada temos que recear. ${ }^{24}$

A confiança inspirou o professor a vencer o temor, extraiu seus saberes para motivar seus alunos e famílias a não perderem o foco de continuar os estudos em casa. Adotou o diálogo, os recursos digitais para persuadir seu auditório escolar nessa nova modalidade de ensino remoto.

\section{A Persuasão}

Conhecer o significado do termo persuadir é essencial, pois para a conquista do auditório há a necessidade de usar a palavra de maneira harmônica, não como imposição, conforme explicita Ferreira:

o termo persuadir origina-se de persuadere (per + suadere). Per, como prefixo, significa "de modo completo". Suadere equivale a "aconselhar". É, pois, levar alguém a aceitar um ponto de vista, é não se valer da palavra como imposição, mas, sim, de modo habilidoso. Persuadir contém em si o convencer (cum + vincere), que equivale a vencer o opositor

21 Ibid., p. 114

22 Ferreira, 2001, p. 174

23 Aristóteles, 1964, p. 35

24 Aristóteles, 1964 
com sua participação, persuadir o outro por meio de provas lógicas, indutivas ou dedutivas. ${ }^{25}$

De acordo com Tringali (2014), persuadir é aconselhar, na persuasão aconselha-se a aceitar uma opinião. Nesse sentido, o orador é um conselheiro e não obrigada o auditório a aceitar sua opinião. Da mesma forma, o professor usa de persuasão nas aulas remotas, tal como um conselheiro, com o objetivo de promover a reflexão e incentivar o aluno a desenvolver habilidades e autonomia necessárias para a continuidade dos estudos.

\section{O ensino remoto}

A mudança no cenário educativo, em decorrência do isolamento social, alterou a vida escolar, evidenciou as falhas e fragilidades da educação e compeliu o professorado a enfrentar obstáculos e a provar que, mesmo diante das adversidades, os profissionais da educação não desistem de seus ideais. Assim, conhecer, assimilar e usar as tecnologias para dar continuidade ao trabalho pedagógico longe da materialidade, por meio de uma tela, fez os professores se apropriarem dos métodos de ensino tanto síncronos como assíncronos, sem perder o foco durante as rotinas de estudos.

O desafio foi lançado a todos, desde a educação infantil até os cursos mais avançados, como as pós-graduações lato e stricto sensu. Contudo, no ensino fundamental, o distanciamento alterou a forma de estudar dos alunos e a maneira de ensinar e intervir do professor. Apesar da existência de um laboratório pedagógico de informática na escola, o uso dos recursos tecnológicos era utilizado mais como um meio recreativo.

Em virtude da pandemia causada pelo Covid-19, o uso das tecnologias digitais se tornou premente. Assim, as concepções e atitudes precisaram se modernizar para se adequarem a uma rotina de estudos fora das paredes da escola. Como Sócrates, o professor abdicou de uma rotina escolar centrada em um espaço físico, em prol de um ensino remoto, dedicando-se aos interesses dos alunos, com mudanças em sua maneira de comunicar, com os seus próprios recursos. Em todos os níveis escolares, exigiu-se adaptação da comunidade escolar para passar do espaço físico da escola para o ambiente virtual da internet. Com isso, a preocupação com a linguagem utilizada passou a ser um dos focos.

25 Ferreira, 2010, p. 15 
Maiêutica socrática e comunicação digital:

paixão e persuasão em tempos de pandemia

Ressaltamos que essa transição abrupta não foi e não tem sido fácil, tanto pela carência de recursos tecnológicos - como equipamentos e acesso de qualidade à internet - quanto pela dificuldade para desenvolvimento de ações de formação voltadas aos professores. Além disso, a necessidade de adequação da linguagem a ser utilizada para persuadir o público é outro fator que merece atenção, uma vez que ela é um instrumento fundamental.

A linguagem é assim instrumento não só de informação, mas basicamente de argumentação e esta, por sua vez, se dá na comunicação e pela comunicação, razão pela qual a argumentação é sempre situada, dando-se basicamente num processo de diálogo, isto é, num contacto entre sujeitos. ${ }^{26}$

A autora ressalta, ainda, que o campo da retórica foi bastante ampliado de Aristóteles aos nossos dias, ${ }^{27}$ nessa perspectiva, Perelman e Olbrechts-Tyteca, reforçam que a concepção de discurso convincente pode ser eficaz no momento oportuno:

o objetivo da argumentação, já o dissemos, é provocar ou aumentar a adesão dos espíritos às teses que se apresentam a seu assentimento: uma argumentação eficaz é a que consegue aumentar essa intensidade de adesão, de forma que se desencadeie nos ouvintes a ação pretendida (ação positiva ou abstenção) ou, pelo menos, crie neles uma disposição para a ação, que se manifestará no momento oportuno. ${ }^{28}$

Diante disso, a argumentação pode ser a chave para a eficácia no ensino remoto, uma vez que ela envolve a elocutio (recursos de expressão), a inventio (buscamos e inventamos os argumentos que melhor atendam aos objetivos de determinada causa) e a dispositio (arranjo das partes). De forma geral, os profissionais envolvidos precisam persuadir esse seu novo auditório, o que requer o envolvimento das artimanhas retóricas mais adequadas para atingir tal propósito.

A persuasão acontece por meio da construção do ethos do orador, com o objetivo de ganhar a adesão do auditório, com investimento na sabedoria (phrónesis) para saber conduzir o trabalho e a benevolência (eunóia) para que a aula remota aconteça. Ademais, movimenta o pathos para articular a aceitação da mensagem e o logos para a construção de uma retórica adequada para esse momento.

26 Mosca, 1997, p. 27

27 Mosca, 1997

28 Perelman; Olbrechts-Tyteca, 1996, p. 50 
O auditório são os alunos do outro lado que enfrentam os mesmos problemas que afligem os professores, como a falta de equipamentos, internet e treinamento para uso das tecnologias. A dificuldade em estabelecer rotina de estudo em casa, pois ao irem à escola, os alunos tinham horário estabelecido para as ações necessárias para estudar. Com o ensino remoto, a autonomia precisa vigorar. Além disso, persuadir o aluno a estudar, a fim de não aumentar a dificuldade e a defasagem é o desafio.

De acordo com Ferreira,

um orador, ao atuar em meio às situações polêmicas e conflituosas do existir em sociedade, vale-se de inúmeras competências e habilidades humanas para agir sobre o mundo por meios persuasivos. Ao exercer um ato retórico (a retórica é material, dinâmica, ativa) e exteriorizar uma proposição, oferece ao outro um compromisso de decisão e, por assim proceder, coloca em jogo o seu próprio ser social. ${ }^{29}$

Portanto, o orador, por meio de seu discurso, deve persuadir o auditório. Para isso, segundo Amossy (2005), precisa treinar o seu discurso para bem apresentá-lo, e essa ação independe de ser presencial ou on-line. No entanto, é essencial ganhar a confiança do auditório para o êxito da empreitada, com base na compreensão de que, como ato retórico, todo discurso deve utilizar de argumentos para atingir um propósito. ${ }^{30}$

\section{Movidos pelas paixões: depoimentos dos professores}

Entre os meses de maio e junho de 2020, durante a pandemia da Covid-19, foi realizada uma pesquisa com dez professores de uma escola municipal de Santo André - EMEIEF Professora Yvonne Zahir, com o objetivo de consolidar informações sobre os aspectos positivos e negativos relacionados ao ensino remoto para os estudantes do ensino fundamental I.

Para este estudo, selecionamos depoimentos e destes recortamos alguns fragmentos para analisarmos as paixões apontadas. Constatamos diversos desafios com os quais os professores se depararam devido à repentina suspensão das aulas presenciais e ao início das aulas remotas e percebemos que as paixões que se destacaram foram temor e confiança. Interessante ressaltar que, ao

29 Ferreira, 2019, p. 9

30 Piovesan; Piovesan, 2019 
Maiêutica socrática e comunicação digital:

paixão e persuasão em tempos de pandemia

apontarem uma dificuldade, ao mesmo tempo apontavam também uma saída para aquela dificuldade.

Professora $\mathbf{E}$ : A minha maior dificuldade frente ao ensino remoto, a princípio, foi lidar com a ansiedade, com a responsabilidade do novo, (...) acostumada a ter tudo planejado, alinhado e sob controle, foi preciso do dia para a noite, sair da zona de conforto e ter que se reinventar no meio dessa confusão.

O aspecto positivo em tudo isso foi a oportunidade de aprender novas práticas, enxergar fora da caixinha, se aprimorar, sair da mesmice, ver novas possibilidades, principalmente nas questões tecnológicas. (...) Passei a valorizar e ver a tecnologia como uma ferramenta poderosa no processo de ensino e aprendizagem desta nova geração.

A professora $\mathrm{E}$ cita como dificuldades a ansiedade, a responsabilidade do novo, o sair da zona de conforto. Em contrapartida, afirma o surgimento da oportunidade de aprender novas práticas, de valorizar a tecnologia como ferramenta no processo de ensino e aprendizagem. Aristóteles afirma que, "para temer é preciso guardar no íntimo alguma esperança de salvação, com respeito àquilo que se luta", ${ }^{11}$ justamente o que a professora E expõe em seu depoimento, ao apontar os temores e, em seguida, a esperança em forma de confiança.

As paixões se complementam quando surge o temor, o qual induz a outras paixões para despertar uma ação, a maiêutica. Nesse caso, ela não se resume apenas em o professor "descobrir a si mesmo", mas também em extrair o que as pessoas sabem, conhecimento necessário aos envolvidos nas aulas remotas. Como explicitado pela professora $\mathbf{E}$, aprender a lidar com a ansiedade e a ver novas possibilidades foi o fio condutor para replanejar suas aulas, convencê-la a recorrer a plataformas, a aprender a usar os recursos tecnológicos e sites gratuitos que não conhecia e a adaptar as atividades propostas em formato digital.

O homem é movido a buscar a verdade que se esconde dentro de si mesmo. Com isso, ele acaba por reconhecer que é capaz de encontrar sua própria salvação, como uma força que o motiva a superar suas limitações. As paixões se complementam quando surge o temor, contudo esse mesmo temor motiva a reagir e a ter atitude para reverter a situação exposta.

$31 \quad$ Aristóteles, 2000, p. 35 
Ao indicar as novas possibilidades para o ensino remoto, principalmente nas questões tecnológicas, os professores esperam que o aluno obtenha um conhecimento que seja capaz de estudar mesmo distante da escola, conforme

a ironia de Sócrates (...) não visa desqualificar o outro, mas ajudá-lo. Ela quer libertá-lo e abri-lo à verdade (...). A ironia procura criar um mal-estar e uma tensão no centro do homem, para que aí proceda o movimento esperado, no próprio interlocutor, se este não puder ser socorrido. $^{32}$

Professora Ke: A princípio foi a dificuldade para utilizar as ferramentas tecnológicas, conhecer plataformas, saber postar, transformar arquivos em $P D F$, tudo que se refere a alfabetizado digital, destacando que sempre tive resistência, uma barreira para usar no dia a dia.

O ponto positivo foi a parceria das professoras no planejamento das propostas para as aulas remotas, no engajamento de trabalho em equipe, nas descobertas, experiências e criações, na expectativa de alcançar as famílias no maior número possível. A aproximação dos alunos e famílias nas conversas a distância, no acreditar que tudo ficaria bem. O diálogo e a cooperação fazem parte das aulas nesse momento, todos com espírito exercendo a empatia. Preocupando-se em como manter uma rotina de estudo sem sufocar as famílias.

A professora Ke destaca o temor frente à utilização das ferramentas tecnológicas, pois, para ela, era algo que não fazia parte de sua rotina educativa. Contudo, ressalta os ganhos obtidos com a nova experiência, como o estabelecimento de parcerias, o trabalho em equipe, o estreitamento de vínculo com as famílias, além da preocupação com o diálogo, com a cooperação e com o cuidado em não sufocar as famílias.

Aristóteles afirma que, para que sintamos temor "é preciso que em nós subsista alguma esperança de nos safarmos da ameaça que nos inquieta", ${ }^{33} \mathrm{e}$ Meyer assegura que "há na alma, ao lado da razão, um princípio ativo e um princípio passivo, ação e paixão se compensando, de certo modo". ${ }^{34} \mathrm{~A}$ professora não deixou que o medo a dominasse, algo que se mostra natural ao ser humano e que transforma a vida.

\footnotetext{
32 Brun, 1984, p. 83

33 Aristóteles, 1964, p. 116

34 Meyer, 2000, p. XXI
} 
Maiêutica socrática e comunicação digital:

paixão e persuasão em tempos de pandemia

A professora ressalta que faz uso do diálogo e da cooperação para enfrentar o momento. Nesse sentido, o diálogo é um princípio da maiêutica para a construção do conhecimento e constitui-se necessário, tendo em vista a mudança de rotina dos estudos e a inevitabilidade de considerar as especificidades de cada família.

Professor R: A maior dificuldade foi trabalhar com as novas tecnologias de vídeo por exemplo, pela timidez, outra questão é a organização do tempo.

O aspecto positivo foi o tempo para pesquisar e trocar conhecimento com outros grupos e outros profissionais.

Um aspecto destacado pelo professor $\mathbf{R}$ foi a dificuldade em se expor no trabalho remoto devido à timidez. Ademais, ele fala da necessidade da organização do tempo, embora não tenha deixado de revelar o temor e a confiança. Para enfrentar seus temores a solução apresentada foi pesquisar, trocar conhecimento com outros grupos e outros profissionais. Nesse sentido, Meyer afirma que

a identidade e a diferença entre os homens exprimem-se e medemse por suas paixões: são índices e, ao mesmo tempo, parâmetros. $\mathrm{O}$ prazer que se quer repetir e o sofrimento que se quer afastar são suas manifestações intrapessoais. ${ }^{35}$

Assim, o temor e a confiança, embora opostos, complementam-se, pois não existiria confiança sem a presença do temor. "Há muitas maneiras de se dominar o medo, uma vez que ele é inevitável, por ser essencial, principalmente, à autopreservação (...) Deve-se evitar o desânimo, o abatimento, para não se deixar vencer pela servidão, pela vassalagem." ${ }^{36}$

Percebemos que embora todos tenham apontado, de início, uma certa insegurança quanto à situação, com o desenrolar do tempo todos se mostraram abertos a sugestões e dispostos a fazerem as adaptações que se mostrassem necessárias.

Para suscitar as adequações com vistas a superar os obstáculos que a atual situação impõe apreendemos a importância da prática da maiêutica socrática, como uma forma de externar o conhecimento guardado e de fazer surgir o reformulado, o inovador, o inesperado, os quais despertam atitude, solicitam a ação e permite a dialética. 
Professora Ka: A maior dificuldade foi não ter precedentes da situação de ensino remoto. A insegurança de não conseguir alcançar todos os alunos e o medo da exposição no nosso trabalho pelos meios digitais.

$O$ aspeto positivo foi descobrir a capacidade de resiliência que eu não sabia que possuía. Nos moldar e adaptar a cada nova circunstância que o ensino remoto nos exige.

A insegurança de não conseguir atender a todos os alunos e o medo da exposição do trabalho nos meios digitais são os temores apontados pela professora Ka. No entanto, ela ressalta a descoberta da capacidade da resiliência e a habilidade de adaptação necessária para o trabalho remoto. De acordo com Aristóteles, "são temíveis aquelas coisas que parecem possuir grande capacidade de arruinar, ou de causar danos que levam a grande desgosto". ${ }^{37}$ coisas que que inspiram compaixão, quando acontecem ou estão para acontecer aos outros.

Também é essencial a coragem para equilibrar o temor e a confiança. Aristóteles ressalta que, embora a coragem se relacione com o medo e com a confiança, a primeira é maior nas situações que inspiram medo, e as últimas, por natureza, suscitam a esperança. Assim, podemos afirmar que maiêutica pode inspirar, sobretudo, no novo cenário no qual se encontram os professores, a trabalhar as habilidades de raciocínio dos alunos por meio do diálogo.

Professor O: O maior desafio foi entender com qual modalidade de ensino iria trabalhar durante o distanciamento social. (...) Outros desafios encontrados são tanto da parte dos alunos, quanto da coordenação e dos docentes, entre eles os mais comuns estão relacionados à questão da quantidade equipamentos tecnológicos para atender a toda à família que estão trabalhando ou estudando em casa. Além disso, a qualidade desses, que tenham capacidade para gravar as videoaulas, (...) a preocupação quanto as questões emocionais que estão interferindo nesse ensino remoto.

Os professores estão mostrando que estão se reinventando e descobrindo possibilidades para o ensino remoto, abriram mão de seu celular ou computador pessoal para terem acesso às famílias: baixaram aplicativos para conversar e interagir com alunos e famílias, (...). Estão garantindo que os alunos tenham acesso a leituras, encaminhando livros em PDF, para que todos tenham acesso. Além disso, na medida do possivel estão dando apoio às famílias, ouvindo-as e compartilhando conhecimento de maneira humanizada. 
Maiêutica socrática e comunicação digital:

O professor $\mathbf{O}$ apontou que o entendimento sobre qual modalidade de ensino iria trabalhar durante o distanciamento social, bem como o problema dos equipamentos tecnológicos e as questões emocionais que interferem no ensino remoto são os maiores desafios. A nosso ver, eles podem ser entendidos como temor:

se o temor é acompanhado de uma expectativa de mal aniquilador, é evidente que ninguém teme entre os que creem que nada poderiam sofrer; não tememos aquilo que não julgamos que poderíamos sofrer, nem aqueles que não se crê que poderiam causar alguma mal, nem mesmo o momento em que não poderia acontecer alguma coisa. Necessariamente, pois, os que pensam que podem sofrer algum mal temem não só as pessoas que podem causá-lo, mas também tais males e o momento da ocorrência. ${ }^{38}$

Nos depoimentos dos professores, destacam-se os medos enfrentados diante dos desafios com as aulas remotas, do uso das tecnologias e da inabilidade. Em contrapartida, a confiança floresce por meio da esperança, da expectativa de se adequar às modernidades e da vontade de dar continuidade ao trabalho pedagógico. Assim,

a confiança é o contrário do temor e o que inspira confiança é o contrário do que provoca temor. Por isso, a esperança segue à representação de que as coisas que nos podem salvar estão próximas e de que não existem ou estão longe das que temos de temer. ${ }^{39}$

Confrontados com a mudança do cenário educativo, os professores não permitiram que o medo destruísse suas ideias; empenharam-se em manter uma rotina, conectando-se de maneiras diversas e ressignificando a maneira de aprender e de ensinar. Nesse sentido, Aristóteles afirma: “a mudança faz-nos sair do estado presente, e o que se produz de quando em quando valoriza as coisas pela raridade". ${ }^{40}$

Atrelado às paixões, quando o professor $\mathbf{O}$ assegura que, além de todas as ações necessárias para o atendimento aos alunos, "apoiam as famílias, ouvindo-as; e compartilham conhecimento de maneira humanizada”. As ideias de Sócrates, com princípio no diálogo e na construção de conhecimento podem ser percebidas

\footnotetext{
38 Ibid., p. 33-35

39 Ibid., p. 35

40 Id., 1964 , p. 75
} 
no depoimento do professor quando afirma ter descoberto possibilidades que envolvem o diálogo, a aproximação com a família e a oferta para interagir por meio de aplicativos. Dessa maneira, "o conhecimento se constrói no confronto dos saberes populares dos oprimidos e das elaborações teóricas dos educadores, sendo o diálogo a forma pedagógica que se dá essa mediação". ${ }^{41}$

Nada mais faço a não ser andar por aí convencendo-vos, jovens e velhos, a não cuidar com tanto afinco do corpo e das riquezas, como de melhorar o mais possível a alma, dizendo-vos que dos haveres não provém a virtude para os homens, mas da virtude provêm os haveres e todos os outros bens particulares e públicos. ${ }^{42}$

Tanto as paixões quanto o método utilizado são essenciais para qualificar a persuasão por parte dos professores diante do auditório escolar e da nova modalidade de ensino remoto por meio da comunicação digital. Tal modalidade pode ser considerada nova no ensino fundamental, em especial da escola pública, pois as aulas eram ministradas presencialmente. Logo, o ensino remoto foi introduzido em decorrência do isolamento social como uma forma de incentivar uma rotina de estudos em casa.

\section{Considerações finais}

Diante do exposto, concluímos que a maiêutica socrática contribui com a construção de argumentos na comunicação digital para persuasão do auditório escolar, com o objetivo de alcançar o sucesso no ensino, bem como a menor perda possível de aprendizagem. Com a análise dos depoimentos dos professores percebemos em destaque as paixões temor e confiança.

$\mathrm{O}$ temor e a confiança permitiram aos professores revelar capacidade de reinvenção e de adequação, conforme a necessidade. Por meio dessas paixões, o professorado foi compelido a criar métodos de ensino remoto e a harmonizar o uso das tecnologias com a arte do bem falar. Esta última é uma estratégia já usada pelo filósofo Sócrates, que se valia da Retórica a fim de convencer ou persuadir seu público com questionamentos que o levavam a raciocinar sobre a subjetividade de um problema.

\footnotetext{
$41 \quad$ Maia, 2008, p. 9

42 Platão, 2004, p. 57
} 
Maiêutica socrática e comunicação digital:

paixão e persuasão em tempos de pandemia

\section{Referências}

AFONSO, E. S. O caráter formativo da noção socrática de "cuidado da alma" no Alcibiades Primeiro de Platão. 2016. Dissertação (Mestrado em Educação) - Universidade de São Paulo, São Paulo.

AMOSSY, R. O ethos na análise do discurso de Dominique Maingueneau. In:

Imagens de si no discurso: a construção do ethos. São Paulo: Contexto, 2005.

ANTISERI, D.; REALE, G. História da filosofia pagã antiga. Trad. Ivo Storniolo. São Paulo: Paulus, 2003.

ARISTÓTELES. Arte Retórica e Arte Poética. Trad. Antônio Pinto de Carvalho. São Paulo: Difusão Europeia do Livro, 1964

. Metafisica. Trad. de V.G.Yebra. Madrid: Gredos, 1998.

. Retórica das paixões. Prefácio Michel Meyer Trad. Isís Borges B. da Fonseca. São Paulo: Martins Fontes, 2000.

Retórica. São Paulo: Edipro, 2013.

AULETE, C. Dicionário Caldas Aulete da língua portuguesa: edição e bolso. $2^{\mathrm{a}}$ ed. - Rio de Janeiro: Lexiblon Editora Digital, 2008.

BECHARA, E. Minidicionário da Língua Portuguesa. Rio de Janeiro: Editora Nova Fronteira, 2009.

BENOIT, A. H. R. Sobre a crítica (dialética) de O capital, in Crítica Marxista. São Paulo: Brasiliense, 1996.

BRUN, J. Sócrates. Trad. Carlos Pitta. Lisboa: Dom Quixote, 1984.

CAMPOS, A. J. V. Q. A Eironeía de Sócrates e a Ironia de Platão nos primeiros diálogos: uma visão crítica sobre a noção de Vlastos de "ironia complexa". 2016. Tese (Doutorado em Filosofia) - Pontifícia Universidade Católica do Rio de Janeiro, Rio de Janeiro. Disponível em: https:/www.maxwell.vrac.puc-rio.br/29362/29362.PDF . Acesso em: 05.set.2020

CARRASCO, C. J. F. O pensamento socrático: a busca da verdade e sua influência na investigação policial. 2013. 78f. Dissertação de Mestrado em 2013) - Faculdade de Direito, Pontifícia Universidade Católica de São Paulo. Disponível em: https://tede2.pucsp. br/bitstream/handle/6131/1/Carlos\%20Jose\%20Favaro\%20Carrasco.pdf

FERREIRA, A.B.H. Miniaurélio Século XXI Escolar: o minidicionário da língua portuguesa. 4. ed. Rio de Janeiro: Nova Fronteira, 2001.

FERREIRA, L. A. Leitura e persuasão: princípios de análise retórica. São Paulo: Contexto, 2010.

. Inteligência Retórica e vocalidade: constituição e manutenção do ethos: In: FERREIRA, L. A (org.). Inteligência retórica: o ethos. São Paulo: Blucher, 2019. p. 9-23

MAIA, M. O. Sócrates e Paulo Freire: aproximações e distanciamentos. Uma introdução ao pensamento educacional. 2008. Dissertação (Mestrado em Educação). Universidade Federal de Pernambuco, Recife.

MEYER, M. Aristóteles ou a retórica das paixões. In: ARISTÓTELES. Retórica das paixões. Trad. Isis Borges da Fonseca. São Paulo: Martins Fontes, 2000. p. XVII-LI

. A Retórica. Revisão Técnica de Lineide Salvador Mosca. Tradução de Marly

N. Peres. São Paulo: Ática, 2007. 
MICHAELIS, Dicionário Brasileiro de Língua Portuguesa. Disponível em: https:// michaelis.uol.com.br/moderno-portugues/busca/portugues-brasileiro/temor/ . Acesso em 16.Out. 2020.

MOSCA, L. L. S. Velhas e novas retóricas: convergências e desdobramentos. In: MOSCA, L. L. S. (org.). Retóricas de ontem e de hoje. 3ª ed. São Paulo: Humanitas, 2004 [1997]. p. 17-54.

PLATÃO. A República. Trad. P. Nassetti. São Paulo: Martin Claret, 2004.

PERELMAN, C.; OLBRECHTS-TYTECA, L. Tratado da Argumentação. A Nova Retórica. São Paulo: Martins Fontes, 1996

PIOSEVAN, E.; PIOSEVAN, R. Ethos institucional e phrónesis na construção de discurso. In: FERREIRA, L. A. (org.). Inteligência Retórica: o ethos. São Paulo: Blucher, 2019. p. 185-202 RODRIGUES, J. P. Sócrates e o seu Método da Maiêutica e a Ironia. PGL.gal. Disponível em: https://pgl.gal/socrates-metodo-da-maieutica-ironia/ . Acesso em 16. Out. 2020.

SAYEG-SIQUEIRA, J. H. A arte de anunciar o medo. In: MAGALHÃES, A. L.; FERREIRA, L. A. (Org.). A Retórica do Medo, 1. ed. São Paulo, 2012. p. 168-174

TRINGALI, D. A retórica antiga e outras retóricas: a retórica como crítica literária. São Paulo: Musa, 2014. 